\title{
The managerial power approach: Is it testable?
}

\author{
Stefan Winter ${ }^{1} \cdot$ Philip Michels ${ }^{2}$
}

Published online: 21 August 2018

(c) The Author(s) 2018

\begin{abstract}
The central hypothesis of the managerial power approach (MPA) states that power is the main driver of executive compensation. The positive impact of power on compensation is allegedly demonstrated by a large number of empirical studies. We argue that the hypothesis of a positive impact of power on pay is not falsifiable empirically. The MPA is thus not testable. Empirical studies in this vein can only be interpreted as validation procedures for the empirical power measures employed. We suggest a new theoretical framework for research on the power-compensation relationship. This framework can be used to identify valid power measures empirically. The arguments presented in our paper allow for a reassessment of the role of power in the corporate governance debate.
\end{abstract}

Keywords Corporate governance $\cdot$ Executive compensation - Managerial power approach $\cdot$ Pay for performance $\cdot$ Board of directors

\section{Introduction}

Broad media coverage, repeated public outrage and legal intervention like the Sarbanes-Oxley and the Dodd-Frank Acts suggest that there might be something wrong with executive compensation in corporate America. Why do executives earn so much? Explanations for the levels of CEO compensation have been a source of controversy amongst economic and legal scholars for decades. At least two opposing views have emerged. The first view can be labeled "optimal contracting", where actual compensation contracts are driven by market forces and are acceptable from

Stefan Winter

stefan.winter@rub.de

Philip Michels

philip.michels@rub.de

1 Chair of Human Resource Management, Ruhr-University Bochum, Universitätsstr. 150, GC 3/159, 44780 Bochum, Germany

2 Chair of Human Resource Management, Ruhr-University Bochum, Universitätsstr. 150, GC 3/158, 44780 Bochum, Germany 
the perspectives of transaction costs and agency theories (see, e.g., Murphy 2002; Kaplan 2008). The second view is labeled "managerial power", where it is held that CEOs receive excessive compensation by exercising their power over captive boards (see, e.g., Bebchuk et al. 2002; Bebchuk and Fried 2004).

After a thorough review of empirical research on the topic, Bebchuk and Fried (2004: 85) concluded: "The evidence indicates that there is a link between managerial power and pay. The more power managers have, the more favorable their compensation arrangements are." In a recent large-scale meta-analysis of 219 US-based studies, van Essen et al. (2015) reached the same conclusion.

We argue that this conjecture is wrong. Managerial power, being consensually defined as a manager's opportunity to take redistributive actions, cannot have a negative impact on compensation by pure logic. By definition "more power" just means "better opportunities". But keeping everything else constant, the very meaning of "better opportunities" suggests that better opportunities cannot lead to worse outcomes for those who possess these better opportunities. If "better opportunities" did lead to worse outcomes i.e., less compensation, what would then be the meaning of "better" and "opportunity"? If power is measured correctly and everything else is appropriately controlled for, logic dictates that it is impossible to find a lack of association or even a negative association between power and compensation empirically. The hypothesis that there is a positive effect of power on compensation is thus not falsifiable empirically and is therefore not testable at all.

Our arguments developed here can help to understand the pattern of interpretations offered in the empirical literature on the power-pay relationship. Empirical studies have employed a large number of different power measures. Each time the measure under test showed a positive association with power, authors concluded that more power leads to higher compensation, implying that the MPA is correct. Each time the measure did not yield a positive association, authors concluded that their power measure was not valid. We found only a couple of deviations from this pattern. In these deviating cases, authors just dropped non-confirming results from any further discussion. So, while we find many papers with either a negative association between the respective power measures and compensation or with a complete lack of association, none of the authors of these studies ever concluded that more power leads to less compensation or that power is unrelated to compensation. This pattern of interpretations suggests that all authors at least implicitly assumed that more power cannot lead to less compensation. While we argue that this assumption is correct, it renders meaningless any empirical effort to prove the existence of a positive relationship between power and compensation.

It is worth noting that our critique of the MPA is not an empirical one because it cannot be an empirical one. Since we argue that the MPA is empirically not testable, we cannot provide empirical evidence to reject this approach. As we will argue later, power cannot be an independent variable in the explanation of managerial compensation at all.

There is consensus that power is not directly observable. It is thus necessary to identify empirical correlates of the power construct. The large number of different power measures in the literature suggests that there is no consensus though on how to measure power empirically. So in fact, authors did not just try to test the 
hypothesis that power drives compensation. Instead, all of them implicitly tested the joint hypothesis that power drives pay and that the respective power measure employed is valid. Since the first part of this joint hypothesis is not testable as outlined above, the only reasonable interpretation of these tests is that they are validity tests only. It is worth noting that the joint hypothesis problem has been almost completely ignored in the literature. One of the notable exceptions was Hill and Phan (1991: 716), who wrote that "we did not measure influence [power] directly, so the results must be interpreted with care."

With respect to the validity problem, it proves useful that power must have a positive impact on compensation already and only by definition. Because if it is known that power must be positively associated with compensation, any power measure that fails to produce the correct sign cannot be valid. This mirrors exactly the pattern of interpretations we found in the empirical literature. Of course, this assumption is only reasonable if other potential influences are adequately controlled for. We identify two important factors that must be taken into account in future efforts to validate empirical power measures. The first factor is the amount of wealth available for redistributive action. The economic value of power is higher the higher are the stakes that can be appropriated. The next factor is the power holder's inclination to use their power. Since by definition power is just an opportunity to take redistributive action, power will have no effect if it is not employed. If, for example, power and the inclination to use it are negatively correlated, one could find a negative association of power and compensation. But this obviously is not the effect of power on compensation, but the effect of different inclinations to actually use power. We are able to identify the functional structure of the way these two factors influence the power-pay relationship. These factors have not been included in the empirical studies up to now. Even results in respect of the validity issue so far may therefore be subject to a severe omitted variable bias. However, our amended version of the moderated power-compensation relationship developed here can be used to improve the validation procedure of empirical power measures.

Proponents of the MPA call for tighter corporate governance legislation in order to limit managerial power (see, e.g., Bebchuk and Fried 2004). They base their arguments on the empirical evidence that more power leads to higher pay. As we argue in this paper, there is no such evidence and there cannot be any such evidence. This implies that any call for corporate governance reforms based on the MPA is unsubstantiated. There may or not may be reasons for tighter regulation of executive compensation, but the MPA does not contribute to this debate.

Our results are also valuable for the evaluation of effects from corporate governance reforms aimed at limiting executive power. If a reform is successful, this does not imply that compensation must decline. For example, it has been argued that the MPA cannot be correct since, in the 1990s, executive compensation rose sharply while many reforms in that era reduced managerial power (e.g., Murphy 2002). One interpretation derived from our model is that the soaring stock market in that decade indicates that the stakes grew bigger. With bigger stakes, even less power may have been sufficient to appropriate more money from shareholders. 


\section{Definition of power}

We will now discuss the definitions of power offered in the literature in detail. The reason being that the main arguments developed in our paper hinge critically on the definition of power. Our thorough review is thus meant to demonstrate that there is complete consensus in the literature on the main aspects of power. Thus, our arguments developed below are not mere contrived results of our own working definition.

Weber (1964, p. 152) defined "power" as the opportunity for individual A to exert their will on individual B to carry out A's will in spite of resistance, and regardless of the circumstances in which this opportunity occurs. Weber argued that power could only develop within a social relationship. The phrase "opportunity" indicated that power was just a means to influence the behavior of others. As Dahl (1957, p. 202) put it: "A has power over B to the extent that he can get B to do something that B would not otherwise do." Like Weber, Dahl also argued that power could only occur within a social relationship. In addition, Dahl determined the constituents of power: its bases, means, scope, amount and extension (Dahl 1957, p. 203; Harsanyi 1964, p. 191).

The bases of power consisted of all resources that an agent could employ in order to affect the behavior of others. Resources to affect behavior could include all kinds of material and immaterial goods or individual skills and abilities (Dahl 1957, p. 203). French and Raven (1959, p. 150) defined five different bases of power: reward power, coercive power, legitimate power, referent power and expert power. Raven (1965) revised this model to include a sixth base: informational power.

Means of power are specific actions which allow A to influence the behavior of B. The scope of power is the set of specific actions that power holder A can induce $\mathrm{B}$ to perform. The amount of power $\mathrm{A}$ has is held in the net increase in the probability that B will do what A wants him to do. It can only be specified in conjunction with the means and scope. The set of individuals over whom an agent has power is called the extension of power (Dahl 1957, p. 203; Harsanyi 1964, p. 184).

Oppenheim (1978, p. 595) explicitly referred to "reward" and "punishment". From his point of view, power held by an individual was nothing more than the ability to make other people do what one wished by means of promised rewards or threats of punishment.

Lambert et al. (1993, p. 441) suggested a definition of managerial power within the managerial compensation context. For them managerial power was "the ability of managers to influence or exert their will or desires on the remuneration decisions made by the board of directors, or perhaps the compensation committee of the board."

It is worth noting that all of these definitions suggested that power should be understood as an ability or opportunity of an agent to influence the behavior of others. To keep the wording simple, we will just use the single term "opportunity" instead of the phrase "opportunity or ability" whenever we talk about 
power. As the working definition for the remainder of this paper, we define "managerial power" in the compensation context as a manager's opportunity to take redistributive measures favoring her- or himself. For the purpose of our paper it is worth noting that there is no dissent in the literature about the opportunity property of power.

One first implication of the opportunity property of power is that power should not be expected to impact on compensation in a deterministic manner. Whether opportunities have any impact depends on the power holders' decisions to make use of their opportunities. The above definition of managerial power implies that if a manager wishes to obtain more money and is already in the possession of power, she could make other people (i.e., members of the board and/or members of the compensation committee) agree to provide more money. In that sense, power can be interpreted as an economic good, a valuable resource that could be exchanged for money. But if, for whatever reason, power holders decide not to exercise their power, there will be no measurable effect of power on compensation. These power holders may still score high on some empirically measured indicator of power, but one would not find a positive effect of the power scores on these power holders' compensation.

Our next point is that the redistributive effects of power are necessarily limited. After all, it is not possible to make other people supply more money than they actually have. This argument addresses the scope of power, which always has an upper limit. No matter what their power is, a CEO of a company with assets worth \$1 million cannot make the board agree to a compensation scheme worth $\$ 1$ billion. In this sense, the redistributive effect of any individual's power is always limited by the size of the cake that is maximally available for redistribution.

\section{Moderators of the power-pay relationship}

From the preceding section, we conclude that power in the compensation context is merely an opportunity to take redistributive actions. Power has no effect when it is not employed. Therefore, power usage is a decision variable that shall be incorporated in any model that aims to describe the relationship between power and compensation. Just assume that there are two types of executives. There are powerful and non-powerful executives. Now assume that, for whatever reason, the powerful ones have a much lower inclination to actually use their power. So in fact they could receive less power-based compensation than their less powerful counterparts. If, however, only power and compensation is observed, one might thus find that power is negatively associated with compensation. But this would not describe the effect of power on compensation, this effect would just be a spurious correlation due to a lack of a control for power usage.

Without loss of generality, assume that power $P$ is defined as a percentage measure, i.e. $P \in[0,1]$, with $P=1$ indicating absolute power, while $P=0$ indicates absence of any power. Again, without loss of generality, assume that the variable "power usage" $U$ is also defined as a percentage measure, i.e. $U \in[0,1]$. While $U=1$ indicates that an agent employs all the power he has, $U=0$ implies that the agent does not use any of his power. 
However, controlling for power usage is only a necessary condition for meaningful analyses. But this control is not sufficient. This is true since the redistributive effects of power will always be limited. We denote the size of the cake by $C$. We define $C$ as the maximum amount of wealth that could eventually be appropriated by a powerful agent. $C$ is measured in monetary units. $C$ also must be controlled for. Assume that there are two types of executives and two types of firms. There are powerful and non-powerful executives. And there are "rich" firms and "poor" firms. Now assume that it happened to be the case that the powerful ones work for the poor firms while the ones with less power work for the rich firms. Having only limited power in a rich firm may still enable the power holder to extract much more money than unlimited power in a poor firm. Having $10 \%$ of power over a huge sum generates more compensation than having $100 \%$ of power over nothing. Again, if only power and compensation is observed in such a situation, one will find that power is negatively associated with compensation. But again, this would not describe the effect of power on compensation, it would just be another spurious correlation.

To summarize, the relationship between power and pay is always moderated by the degree of power usage $(U)$ and the size of cake $(C)$. Any attempt to estimate a functional relationship between power $(P)$ and the additional compensation $(Y)$ derived by exercising power e.g., $Y=f(P)$, is thus highly likely to yield biased results due to an omitted variables problem. Instead, research must specify the relationship as $Y=f(P ; U ; C)$.

The definition of power and the conclusions drawn from that definition allow us to derive the specification of the functional form of $f$. This is true, as the definition provides for some initial conditions for $f$. First of all, if the value of any of the $P, U$, and $C$ variables is zero, then $Y$ must be zero. This is because if there is no power, if power is not utilized at all, or there is no cake, then pure logic dictates that there can be no power-based compensation $Y$. Since power-based compensation is zero if any of the variables $P, U$, or $C$ are zero, these variables must interact multiplicatively. Also by pure logic one can infer what must happen if an agent has absolute power and fully uses it. If agents have absolute power i.e., $P=1$, this means they have the opportunity to make others give them all the money these others have i.e., the whole cake $C$. So if they use all this power i.e., $U=1$, the whole cake must go to the power holder. Taken together, the function $f(P ; U ; C)$ must satisfy the following four conditions:

(I) $f(0 ; U ; C)=0$

(II) $\quad f(P ; 0 ; C)=0$

(III) $\quad f(P ; U ; 0)=0$

(IV) $\quad f(1 ; 1 ; C)=C$

The specification that meets all these conditions is:

$$
Y \equiv P^{a} \cdot U^{b} \cdot C
$$

with constants $a, b>0$. Since $a$ and $b$ are scaling factors only, they can be eliminated by an appropriate adjustment of the original $P$ and $U$ measures. If one feeds in the transformed measures $P_{t}=P^{a}$ and $U_{t}=U^{b}$ in equation $Y \equiv P^{a} \cdot U^{b} \cdot C$ one gets: 


$$
Y \equiv P_{t} \cdot U_{t} \cdot C
$$

We only refer to this latter specification in what follows and drop subscripts $t$ for ease of notation.

Thus, the first central proposition of our paper is that the so far used specification of the power-pay relationship of the form $Y=f(P)$ is misspecified. The correct specification must read $Y=f(P ; U ; C)$. Empirical research based on the former specification suffers from an omitted variable bias. (See Appendix 1 for a more detailed discussion of the omitted variable problem.)

What are the further consequences of our specification for empirical tests of the existence of a power-pay relationship? First, we note that the Eq. (2) derived above is nothing more than a mathematical representation of the definition of power and the implications directly derived from that definition. This implies that if $U$ and $C$ are held constant, compensation $Y$ must increase when power $P$ increases. This must hold true by definition and by definition alone.

Let us put our rationale in a neutral context first. Power means that whatever you want, you can make it happen. This is how power is defined. If you want $X$ to happen and you have power, you can make $X$ happen. You cannot test this conjecture because this conjecture is a logical consequence of a definition. If now someone finds cross sectionally that power has no or even a negative impact on the occurrence of $X$, this does not imply that power has no impact on $X$, it just means that power holders have no or differing preferences for $X$. If you control for (differing) preferences, you will and must find a positive impact of power on $X$, because power is defined as the ability of the power holder to make $X$ happen. Finding no or a negative relation between power and $X$ thus just means that you have not controlled adequately for power holders' preferences for $X$.

How much power based compensation will an agent receive who has no power at all or who uses no power at all or who is in a situation with absolutely no money available? Nothing. And this again is for purely logical reasons. But the opposite then must also be true: If you have power, i.e. the opportunity to get the money you want, and if you make use of this opportunity and if there really is money available, then the effect of your power will be that it brings you the money you desire. Again, this conjecture is a purely logical one. It is thus not empirically testable. That's our main claim. Controlling for power usage und cake size, the effect of power on compensation exists and is positive, but for purely logical reasons. Whether or not such an impact exists cannot be evaluated empirically.

We therefore argue that, with everything else kept constant, power has and must have a positive impact on pay by definition and by definition alone. It is therefore futile to try to establish the existence of a relationship between power and pay empirically. With respect to the MPA, this conjecture has two implications. The first is that with everything else kept constant, the main "theoretical" claim of the MPA i.e., that more power leads to higher compensation, is correct. It is logically correct since it follows directly from the definition of power. The second implication is that the main empirical claim of the MPA's proponents i.e., that the existence of such an effect of power on pay has been empirically established, is not correct. 
It is impossible to establish the existence of a relationship between power and compensation empirically. But since this relationship exists by definition, one might still be interested in the economic significance of the effect of power on compensation. Unfortunately this question also cannot be addressed empirically. To see this, assume that all variables involved can be measured without error. In this case, the marginal effect of power on compensation is $d Y / d P=U \cdot C$. But this effect again is solely derived by an analysis of the definition of power and the implications deduced from that definition. If empirically one finds something else, this would only mean that at least one variable has not been measured correctly.

Thus, the second central proposition of our paper is that any kind of empirical research that tries to establish the existence of a positive power-pay relationship can yield tautological results only. The managerial power hypothesis is empirically not testable. Therefore, empirical evidence corroborating the MPA does not and cannot exist.

Our overall conclusion is that any kind of empirical research that treats power as an independent variable that determines executive compensation is condemned to be meaningless. This does by no means imply that power is a useless construct in research on corporate governance mechanisms. Indeed, we suggest some future research avenues below that look really promising to us. It does imply, though, that any efforts to establish the existence of a power pay relationship or to estimate the economic significance of such an effect should be completely abandoned.

\section{Reexamination of empirical research}

There are numerous papers demonstrating relationships between executive compensation and various corporate governance measures. The most prominent measures deal with the ownership structure of the firm, the board structure/composition or with CEO characteristics. A wide array of other miscellaneous variables are typically addressed in only one or a very small number of studies. The following Table 1 presents a sample of some of these measures.

We now turn to a more systematic analysis of the power measures in the empirical literature. We identified more than 30 different corporate governance measures that have been explicitly interpreted as indicators of managerial power in at least one study each. This large number of different measures implies that there is no single, generally accepted empirical measure of power. It could thus be that the choice of the power measure has a direct impact on the results. Indeed, some of the measures like CEO duality were typically positively associated with executive compensation (see, e.g., Boyd 1994; Core et al. 1999), while others showed no relationship at all. Some measures like CEO ownership usually produced negative coefficients (see, e.g., Khan et al. 2005; Lambert et al. 1993). More complex functional forms, such as inverted u-shaped relationships, were also found (see, e.g., Finkelstein and Hambrick 1989).

In what follows, we restrict our analysis to seven out of these more than 30 different power measures. This restriction allows us to concentrate on measures that have been employed in at least 40 estimated econometric models each. We are thus able 
Table 1 Sample of corporate governance measures used in CEO compensation research

\begin{tabular}{|c|c|}
\hline Measure & Studies \\
\hline \multicolumn{2}{|l|}{ Ownership structure } \\
\hline Existence of a majority shareholder* & $\begin{array}{l}\text { e.g., Cyert et al. (2002), Fahlenbrach (2009), Fong } \\
\text { et al. (2010), Kim (2010), Becker et al. (2011) }\end{array}$ \\
\hline Institutional ownership concentration* & $\begin{array}{l}\text { e.g., Hartzell and Starks (2003), Almazan et al. } \\
\text { (2005), Chhaochharia and Grinstein (2009) }\end{array}$ \\
\hline $\begin{array}{l}\text { Percentage held by pressure resistant institutional } \\
\text { investors }\end{array}$ & e.g. David et al. (1998) \\
\hline Percentage of shares held by members of the board & $\begin{array}{l}\text { e.g., Bertrand and Mullainathan (2001), Chhaoch- } \\
\text { haria and Grinstein (2009) }\end{array}$ \\
\hline CEO ownership* & e.g., Khan et al. (2005), Lambert et al. (1993) \\
\hline Percentage of local ownership & e.g., Chhaochharia et al. (2012) \\
\hline \multicolumn{2}{|l|}{ Board/committee structure } \\
\hline CEO is also chair of the board* & e.g., Fahlenbrach (2009), O’Reilly and Main (2010) \\
\hline Age of board members & e.g., Core et al. (1999) \\
\hline $\begin{array}{l}\text { Number of other board positions held by board } \\
\text { members }\end{array}$ & e.g., Core et al. (1999) \\
\hline Board size* & e.g., Yermack (1996), Cheng (2008) \\
\hline Composition of compensation committee & e.g., Newman and Mozes (1999) \\
\hline Percentage of outside (inside) directors* & e.g., Grinstein and Hribar (2004), Boyd (1994) \\
\hline Interlocking directorates & e.g., Hallock (1997) \\
\hline \multicolumn{2}{|l|}{ CEO characteristics } \\
\hline CEO tenure* & e.g., Brookman and Thistle (2009) \\
\hline Relative tenure of CEO vs. board members & e.g., Wade et al. (1990) \\
\hline Celebrity status & $\begin{array}{l}\text { e.g., Malmendier and Tate (2009), Wade et al. } \\
\text { (2006) }\end{array}$ \\
\hline \multicolumn{2}{|l|}{ Other measures } \\
\hline Charter without anti-takeover amendments & e.g., Borokhovic et al. (1997) \\
\hline Existence of anti-takeover legislation & $\begin{array}{l}\text { e.g., Bertrand and Mullainathan (2000), Cheng and } \\
\text { Indjejikian (2009) }\end{array}$ \\
\hline Media influence & e.g., Core et al. (2008) \\
\hline
\end{tabular}

Variables denoted with * are those that we analyze in more detail below

to compare for the seven measures chosen the treatment and results of any of these variables across a reasonable number of documented estimations. We also choose to limit ourselves to this number because the overall treatment of the different measures is virtually the same across all measures. Our sampling criteria led to the exclusion of some of the most recent studies in the field, e.g. Ataay (2018), Korkeamaki et al. (2017), Qian et al. (2018) and others. But the results presented here do not depend on the criteria used to select the studies we review.

In the following sections, we differentiate between two types of studies. Type 1 is those studies that define a corporate governance variable $\mathrm{x}$ explicitly as a power measure and then try to test the main hypothesis of the MPA i.e., that more power leads to higher compensation. Type 2 is those studies that also employ the same 
variable $\mathrm{x}$ but do not interpret $\mathrm{x}$ as a power measure and/or use $\mathrm{x}$ only as a control variable. Thus, authors of Type 2 studies mainly do not refer to the MPA at all. But even if they do, they use the power measure as a control variable only. Authors of Type 2 studies usually do not offer interpretations of their findings with respect to $\mathrm{x}$. In this section we examine the interpretations offered in the literature. Since interpretations can only be found in Type 1 studies, we restrict ourselves to a review of these studies here. We come back to the Type 2 studies later on.

\subsection{Reevaluation of Type 1 studies}

This section deals with author's interpretations of their results concerning the effects of their different power measures on compensation. As we have argued above, the effect of power on compensation must be positive. If no or a negative impact is found, there are only two possible explanations: The estimated models are misspecified or the variables employed are not valid. Our literature review reveals that authors generally assume invalid measures in case of unexpected findings.

\subsubsection{Insider ratio}

We begin our review with the "insider ratio", which corresponds to the percentage of inside directors serving on the board. It was expected that a higher proportion of insiders would be indicative of greater managerial power (Boyd 1994; Grinstein and Hribar 2004) as insiders are considered more dependent on the CEO than outside directors.

Grinstein and Hribar (2004, p. 135) only found an insignificant positive effect and wrote: "The Insider Ratio coefficient is positive in all three specifications but is not significant at conventional levels. This result is consistent with Core et al. (1999) who do not find a significant relationship between the insider ratio and managerial compensation, and might suggest that our measure of insiders is a very noisy proxy for board independence."

Boyd (1994) also interpreted the insider ratio as a power measure and found a negative effect of the insider ratio on compensation. But he did not conclude that more power led to lower pay. Instead, he wrote that "Research presented here supports the work by Mizruchi (1983) and others who argued for a very different role of inside directors. Mizruchi suggested that inside directors will feel as if they are being evaluated by outside directors. Inside directors, particularly those considered as possible successors to the CEO, may fear the appearance of siding with the CEO, and alienating outside board members. Baysinger and Hoskisson (1990) also argued that legal obligations and concern for professional reputation will cause inside directors to limit their support for the CEO" (Boyd 1994, p. 341).

Ghosh and Sirmans (2005) also found a negative effect of the insider ratio on CEO compensation. They offered the following interpretation: "This evidence [...] brings in question the monitoring effectiveness of additional outside directors and casts doubt on the popular contention that outside directors are better monitors than insider directors" (Ghosh and Sirmans 2005, p. 418). 
In effect, we did not find a single Type 1 study that found a positive association between the insider ratio and executive compensation. On the other hand, in no case a disconfirming result was interpreted as evidence that power tends to reduce compensation or that there is no relation at all. Instead, all authors argued that the insider ratio might not be a valid indicator of power.

\subsubsection{Percentage of outside directors}

The percentage of outside directors was suggested to be an inverse measure of power (Lambert et al. 1993, p. 445). Outsiders were assumed to be more independent from the CEO, such that a CEO with an outsider-controlled board was expected to have less power. The interpretation of the percentage of outside directors as an inverse power measure directly mirrors the interpretation of the insider ratio above.

Lambert et al. (1993, p. 455) found "an unexpected positive association between the percentage of external board members and the level of executive compensation". This result went without any further comment. In particular, the authors did not conclude that more power led to less pay. Shin (2016, p. 441) also did not find the expected effect and concluded that this measure of managerial power "may be too subtle to capture the CEO's formal authority".

Mangel and Singh (1993) also found a positive impact. They argued: "The percentage of outside directors shows a slight but not significant positive relationship to cash compensation. Perhaps this finding stems from the preponderance of outside directors on the boards of very large organizations. In our sample the mean board was almost $75 \%$ outsiders and there were very few boards that had fewer than $50 \%$ outsiders. Our collection of firms might thus already have [a] sufficiently high percentage of outside directors as board members" (Mangel and Singh 1993, p. 347).

Again, the conclusions drawn by all authors were concerned with the validity of the power measure, rather than concluding that more power led to less pay.

\subsubsection{Board size}

Board size was also assumed to represent a power measure. It was argued that ingroup monitoring and collective action problems associated with larger boards provided executives with more power over the pay setting process (Eisenberg et al. 1998; Sapp 2008). According to this conjecture, a positive effect of board size on CEO compensation was expected.

Ghosh and Sirmans (2005, p. 413) found the expected positive effect and concluded: "Larger boards are less effective in monitoring because of lack of interaction, and a lack of focus due to potentially wide dispersion in directors' background, expertise, and interests. Under these circumstances, directors are likely to be retained less for their contribution, and more as a quid-pro-quo for their personal relationship with the CEO, resulting in lax monitoring and higher CEO pay."

Van Essen et al. (2015) also found a positive effect as expected. The authors noted: "In assessing the evidence regarding the relationship between managerial power and total compensation levels, we find overall support for the MPT [Managerial Power Theory]. Two of the three indicators of CEO power (board size and CEO 
duality) are positively associated with total pay, suggesting that in most situations where CEOs are expected to have more power over the pay-setting process, they have higher levels of total compensation" (van Essen et al. 2015, p. 183).

The conclusions in both studies are exactly in line with the managerial power hypothesis, as are the empirical results.

On the other hand, Grinstein and Hribar (2004) found the opposite. They wrote: "One interpretation of this finding is that when the CEO is more involved in choosing board members, a smaller board might actually mean that the CEO has more managerial power" (Grinstein and Hribar 2004, p. 136). Here, results were not in line with expectations, but authors did not conclude that more power tends to reduce pay. Instead, it is concluded that smaller rather than bigger boards are indicative of managerial power. This means that ex post the dependent variable is used to explain the meaning of the independent one.

\subsubsection{CEO ownership}

CEO ownership has also been used as an indicator of CEO power. It was assumed that executives who owned significant portions of their firms were likely to control board decisions and thus have more power (Finkelstein and Hambrick 1989).

Finkelstein and Hambrick (1989) found an inverted U-shape relationship, where compensation increased up to an ownership level of nine percent and then started to decline. The authors interpreted this result as evidence that more power led to more pay. The reason offered for the negative effect for higher ownership stakes above nine percent was "thought to lie in the [...] tax advantages of keeping money in the firm and reaping capital gains instead of current income" (Finkelstein and Hambrick 1989, p. 130). No reason was offered to explain why the confirming part of the inverted u-shape relationship was taken as evidence of a positive impact of power on pay, while the disconfirming part was argued to be of no relevance.

Khan et al. (2005) also interpreted CEO ownership as an indicator of power and expected a positive effect on total compensation. They found no effect at all for total compensation but offered no further discussion on the issue.

Lambert et al. (1993: 455) found a negative impact of the ownership variable on compensation, despite expecting to find a positive one, and explained this as follows: "One potential explanation for this result is that the corporate CEO's compensation is a benchmark for lower-level managers' compensation. Specifically, if CEO compensation is decreased, this will produce large decreases in total organizational compensation and an increase in the equity value of the firm. Thus, it can be optimal for a CEO with a high equity ownership to have a low level of compensation because this decrease is more than offset by an increase in the value of equity owned by the CEO."

A similar argument was put forward by Finkelstein and Hambrick (1989) with respect to the CEO's family holdings. While it was expected that family holdings would contribute to CEO power and thus compensation, the opposite effect was found to be true. Finkelstein and Hambrick (1989, p. 130) suggested: "Perhaps it is in the best interest to keep CEO pay low as a signal to other organizational members to limit their expectations." Alternatively, they argued that "it may be that relatives 
are especially watchful and exert tight control over the CEO”. By this, the ex-ante power measure was turned into an ex-post measure of surveillance. Taken together, the CEO ownership variable almost completely contradicted expectations, yet none of the authors concluded that more power resulted in lower pay.

\subsubsection{CEO duality}

Some authors argued that CEO duality i.e., where the CEO also served as chairman of the board, indicated more CEO power (e.g., Boyd 1994; Core et al. 1999). Accordingly, CEO duality was expected to have a positive impact on CEO compensation.

Noguera and Highfield (2006) found the expected effect. They noted: "This is consistent with the idea that as the CEO has more power over the board, he is more able to extract additional compensation." (Noguera and Highfield 2006, p. 31). Grinstein and Hribar (2004, p. 135) also found this effect and concluded: "The positive sign of these two coefficients suggests that CEOs with greater board influence earn greater bonuses." In the same vein, van Essen et al. (2015, p. 183) noted: "Two of the three indicators of CEO Power (board size and CEO duality) are positively associated with total pay, suggesting that in most situations where CEOs are expected to have more power over the pay setting process, they have higher levels of total compensation."

Otten and Heugens (2008, p. 43) interpreted their confirming results as follows: "In line with previous research results (...), CEO duality seems to adequately capture executives' power in relation to setting pay levels and structures." This interpretation is obviously not concerned with the power-compensation hypothesis but the results are taken as evidence that CEO duality is a valid measure.

Conyon and Peck (1998) found no support for a positive duality impact. They noted: "Again, we found little support for this hypothesis; CEO duality, contrary to our expectations, (...) also appeared to play little role in shaping top management pay. (...) Our results somewhat surprisingly indicated that CEO duality was not a robust driver of U.K. management pay in our sample of companies, suggesting that empirically, duality does not fully capture CEO power in relation to establishing pay" (Conyon and Peck 1998, pp. 154-155). Again, a non-confirming result was not interpreted as evidence against the main MPA hypothesis but as evidence that the empirical power measure was not valid.

Renneboog and Zhao (2011, p. 1150) found a negative impact, to which they remarked: "Combining the function of CEO with the tasks of the chairman seems to decrease his salary. However, further investigation reveals that the combination of both functions is almost exclusive to small companies where the CEO compensation is lower."

\subsubsection{CEO tenure}

Another variable under scrutiny was CEO tenure. Longer tenure was assumed to indicate more power, as a CEO with longer tenure had more time for network 
building and could be expected to have more influence on directors and internal pay practices (Bebchuk et al. 2010, p. 2390).

Davila and Venkatachalam (2004, p. 456) found the expected effect and concluded: "Tenure is positively associated with both cash and total compensation, consistent with CEO power being translated in higher compensation." Bebchuk et al. (2010) found a positive effect of tenure on the odds of getting a lucky stock option grant, and interpreted this finding as evidence that power had a positive impact on compensation (Bebchuk et al. 2010, p. 2390).

Cyert et al. (2002) found a positive effect of tenure on base salary. They concluded: "Finally, the coefficients on CEO tenure and age are generally positive for base salary, but are significantly negative for the non-salary components. The positive coefficient for tenure for base salary appears to be consistent with the managerial power theory that argues for a positive relation of CEO power to her tenure" (Cyert et al. 2002, 466). This interpretation is especially interesting in our context because the authors do not claim that more power leads to more compensation but that tenure is a measure of power. The fact that tenure affects non-salary components significantly negative went by without comment.

Finkelstein and Hambrick (1989) found an inverted U-shaped relationship with pay increasing in tenure and starting to drop after 18 years of tenure. The authors suggested as one potential explanation "that power accrues for a while and then diminishes, due to the CEO's reduced mobility in the managerial labor market" (Finkelstein and Hambrick 1989, p. 129). This interpretation obviously reversed the a priori logic, because the dependent variable was now used to explain the independent one over the interval of the negative association between tenure and compensation i.e., if pay dropped, this must imply that power also dropped.

Elhagrasey et al. (1999) also found an inverted U-shaped relationship. They concluded: "One indicator of power, CEO tenure, shows a strong curvilinear effect on CEO compensation, rising to a maximum at 16.5 years. (...) The evidence is consistent with the CEO power perspective. CEO compensation is related to indicators of institutionalized CEO power such as tenure as CEO and holding the board chair position" (Elhagrasey et al. 1999, pp. 324-327). Although these authors also found a strong curvilinear effect very similar to that of Finkelstein and Hambrick (1989), the negative part of the tenure/compensation relationship was not discussed further.

The meta-analysis by van Essen et al. (2015) did not find a positive association between tenure and pay. The authors did not provide a reasonable explanation for the missing link between tenure and total compensation. For our purposes it is noteworthy that they did not conclude that power had no effect on compensation. Finkelstein and Boyd (1998) found a negative effect of tenure on compensation but did not offer any comment. The same holds true for Sapp (2008).

Again, non-confirming results are declared inconclusive or are dropped from any further discussion altogether.

\subsubsection{Institutional investors}

It is argued that institutional investors monitor managers more actively and are more able to constrain executive power. The existence of an institutional investor is thus 
expected to reduce managerial compensation (van Essen et al. 2015, p. 172). The existence of an institutional investor can thus be interpreted as an inverse measure of managerial power. The treatment of institutional investors in the econometric models surveyed is quite heterogeneous. Most times, institutional investors enter the equations as 0/1 dummies indicating whether there is an institutional investor at all. Typical thresholds are $2.5 \%$ or $5 \%$. Other models use institutional investor concentration ratios or the percentage owned by the $\mathrm{x}$ largest investors taken together. We therefore give details on the respective measurement approach below.

Khan et al. (2005) employ different approaches to estimate the effects of institutional investors on CEO compensation. One approach was to measure the percentage of equity owned by the largest institutional investor. They found the expected effect and concluded: "Large institutional owners are more effective in reducing levels of salary, options, and total compensation by reducing managerial discretion in compensation decisions" (Khan et al. 2005, p. 1084). Another measure employed in this study was the number of investors holding at least $5 \%$ each. The expected effect was not found for this variable. The authors commented: "We find no significant relationships between block ownership and compensation, in contrast to previous literature that suggests that $5 \%$ concentration of ownership is required for effective control. There are two possible explanations for this result. First, 5\% cut-offs may not be meaningful. (...) Second, using only the number of blockholders does not include the characteristics of a blockholder" (Khan et al. 2005, p. 1086). Again we see the known pattern. If a measure generates expected results, results are accepted, but if the measure fails, it is declared invalid.

David et al. (1998) differentiated between three types of investors. Only for the group of investors that had no other relation to the respective firms besides being investors, did the authors find the expected effect. They noted: "The presence of pressure-resistant institutions that had an exclusively investment relationship with firms and did not depend on the firms for business reduced the level of their CEOs' pay" (David et al. 1998, p. 205). By classifying different types of investors, the authors actually tested the hypothesis that their category of "pressure resistant institutions" was sensibly labelled.

\subsection{Reevaluation of Type 2 studies}

Authors of Type 2 studies employ the same variables that have just been discussed above. The difference is that in Type 2 studies these variables are either not interpreted as power measures or they are only included as control variables. Authors of these studies typically do not offer interpretations of their results with respect to these variables. If, however, these variables indeed would be valid measures of power, results of Type 2 studies should find positive effects on compensation.

We selected our sample of studies by starting from the selection used in the large scale meta-analysis of van Essen et al. (2015). From this set we excluded those studies that did not meet our selection criteria, i.e. had not used one of our seven power measures or used very narrow compensation measures. We then made citation and keyword searches to detect other studies that meet our criteria and have not been 
Table 2 Summary of regression coefficients

\begin{tabular}{|c|c|c|c|c|c|}
\hline \multirow[t]{2}{*}{ Variable } & \multicolumn{2}{|l|}{ Expectation met } & \multicolumn{2}{|c|}{ Expectation not met } & \multirow{2}{*}{$\begin{array}{l}\text { Expectation met and } \\
\text { significant (in \%) }\end{array}$} \\
\hline & Not significant & Significant & Not significant & Significant & \\
\hline Insider ratio & 15 & 10 & 18 & 5 & 0.208 \\
\hline$\%$ of Outside directors & 8 & 0 & 18 & 15 & 0.000 \\
\hline Board size & 11 & 8 & 11 & 10 & 0.200 \\
\hline CEO ownership & 14 & 18 & 24 & 34 & 0.200 \\
\hline CEO duality & 21 & 33 & 8 & 13 & 0.440 \\
\hline CEO tenure & 45 & 103 & 59 & 17 & 0.460 \\
\hline Institutional investors & 8 & 14 & 8 & 12 & 0.333 \\
\hline Total & 122 & 186 & 146 & 106 & 0.332 \\
\hline
\end{tabular}

Source: Authors' calculations

The studies we used to calculate the above figures are listed in Table 3 in Appendix 2. If a study presents more than one estimated model, we only include the model(s) with the broadest compensation measure, ideally total compensation. If total compensation as the depended variable was not employed, we included the model with the broadest cash compensation measure, typically salary plus bonus. Other delineations of the compensation measures had no measurable effects on our calculations or on our interpretations

covered by van Essen et al. (2015). In total, we identified 69 studies that we used for the following analysis.

Since power must have a positive effect on pay if $U$ and $C$ are adequately controlled for, any measure that does not yield a positive coefficient can be dismissed as invalid. This is exactly how the empirical literature of Type 1 studies has argued so far. Each time a power measure under test did not yield a positive coefficient, the measure was dismissed for a lack of validity.

None of the variables discussed above unequivocally meet the validity condition that power must impact on pay positively. In the studies of Type 1 plus those of Type 2 we considered for our review, the seven variables were used in 560 documented regression models. None of the measures were significantly associated with executive compensation in the right direction in more than $50 \%$ of the estimated models (see Table 2). Although none of the studies reviewed appropriately controlled for $U$ and $C$, we see no a priori reason why the moderating effect of these variables should have markedly changed the results presented in Table 2.

Given that a valid power measure must yield unequivocal results, all seven of our measures perform quite badly, with tenure and duality performing relatively best.

\subsection{Summary}

To summarize, a clear pattern emerged from all these tests. When an empirical power measure under examination showed the expected impact on pay, the measure was assumed valid and it was concluded that power impacted positively on pay. When no effect or a negative effect was found, the variable was dismissed as invalid. Not all authors made explicit claims about the lack of validity, and indeed many of them simply dropped non-confirming results from their discussion sections 
altogether. It is clear that by dismissing the non-confirming results each time, the whole empirical approach can only yield tautological conclusions. It is simply futile to repeatedly test for a positive association with different measures if only measures showing the expected results are accepted as conclusive.

Thus, the third proposition of our paper is that empirical research on the managerial power hypothesis so far has only produced non-results based on circular reasoning. From our propositions one and two above it was clear that nothing else could be expected. What is more, the power measures that have been employed so far perform rather poorly with respect to their validity characteristics. This latter judgement is somewhat speculative though, since none of these studies have adequately controlled for $U$ and $C$.

\section{Avenues for future research}

Above, we have concluded that empirical research on the existence of an impact of power on compensation is meaningless. While at first sight this seems to be a devastating judgment, the fact that power must impact on pay for logical reasons alone is in fact a valuable insight that can guide interesting empirical research. We suggest three different directions for further research. We will begin with a fourth recommendation that does not follow directly from our model but is rather a prerequisite to follow the other three directions.

\subsection{Disentangling of compensation determinants}

In this paper we have discussed power driven compensation alone. But neither we nor the advocates of the MPA suggest that all compensation is driven by power alone. This implies that procedures must be developed to separate the power driven part of compensation from the part that is determined by other factors like e.g. human capital, forces of demand and supply, firm characteristics, and so on. Let $Y_{T}$ be total compensation and $Y_{M}$ be that part of compensation that is determined by market forces, or rather by all forces but power. In line with the notation used throughout this paper, $Y$ still denotes power based compensation satisfying $Y=P \cdot U \cdot C$. We would then have $Y_{T}=Y_{M}+Y$. Separating $Y_{M}$ from $Y$ may now not be as easy as it may seem at first sight. Here we give only one example of a problem that might arise. If market forces dictate that there should be some pay for performance, then $Y_{M}$ will be higher for executives that perform good. However, a good firm performance might as well indicate that there is much money available that can be appropriated, i.e. cake size $\mathrm{C}$ is high. This implies that power based compensation $\mathrm{Y}$ might increase at the same time as pay for performance and both increases are due to an increase of the same variable. It might thus not be trivial to separate these effects. But since the specification of the power-pay-relationship $Y=P \cdot U \cdot C$ is precisely known, separating these effects should be possible. 


\subsection{Validation of measures}

As suggested above, the empirical research branch of the MPA is actually concerned with the validation of power measures. But up to now, no undoubtedly valid measure has been identified. So what can be done? One validation strategy would be to refine the measures that have been used before. This refinement strategy has already been employed in the literature a couple of times. For example, the outsider ratio was expected to be an inverse measure of power. However, results typically failed to produce the "correct" effect. A refinement suggested in the literature was to consider that outside directors that took office after the incumbent CEO actually increased power. It was argued that the CEO may already have had an influence on the selection of these outsiders. Thus, although still being outsiders, these directors may feel indebted to the CEO. Shin (2016, p. 439) found the percentage of outside directors appointed after the CEO took office to be positively associated with CEO compensation, and concluded that the power hypothesis could only be supported when this measure was taken as the power measure. Lambert et al. (1993) used the same refinement and reached the same conclusion. A similiar refinement strategy was used by David et al. (1998) for the institutional ownership variable. While this variable performed relatively well, it still failed to produce unequivocal results. David et al. (1998) then differentiated between different types of institutional investors. For those investors that had no other relationships with the respective firms, they found the expected negative effect on CEO compensation. This result suggests that not all types of institutional investors should be expected to limit managerial power.

While refinement of variables seems to be a promising approach, validation procedures must still adequately control for $U$ and $C$. This has hardly been done so far. We found one notable exception with respect to cake size $C$. Grinstein and Hribar (2004) made an interesting observation. They constructed four groups of executives based on an index of power by summing up the values of three different power measures. They observed that M\&A bonuses for the most powerful group were slightly less than bonuses for the least powerful ones. At first sight, this would contradict the MPA. But then they divided bonuses by deal size and found that the most powerful group had a bonus/deal size ratio of $0.1188 \%$, while the least powerful had a ratio of only $0.0538 \%$ (Grinstein and Hribar 2004, p. 139). The deal size could eventually serve as the cake size measure $C$. If compensation $Y$ is divided by $\mathrm{C}$, we obtain $P \cdot U=Y / C$. If now it is assumed that $U$ is constant across executives i.e., $U=k$, we get $k P=Y / C$. In that case the term $Y / C$ measures power. A higher ratio thus implies more power. If now $Y / C$ is positively associated with an empirically observed power measure, this measure passes the validity check. Since Grinstein and Hribar (2004) had constructed a power index to define the four subgroups and the bonus/deal size ratio was indeed highest for the most powerful executives and lowest for the least powerful ones, their index might be valid. We use the phrase "might be valid" since Grinstein and Hribar (2004) still do not control for $U$, but their approach heads in the right direction with respect to the treatment of $C$.

Our own model equation $Y=P \cdot U \cdot C$ can also be used in a validation procedure of empirical measures. This equation represents the definition of power and the implications derived from that definition. If measures are valid and if there 
are no measurement errors, then this equation must hold exactly for each executive. So if variable $y$ is assumed to be a measure of power-based compensation, $p$ is assumed to be a measure of power and $u$ and $c$ are defined accordingly, the empirical result for each executive $i$ must be that $y_{i}=p_{i} \cdot u_{i} \cdot c_{i}$. A joint test of the validity of the three measures could be constructed as follows. Taking logarithms of our model equation one obtains: $\log Y=\log P+\log U+\log C$. The empirical model thus would read $\log y=\beta_{1} \log p+\beta_{2} \log u+\beta_{3} \log c$. Assuming that $y$ is a valid measure of power-based compensation, then the $p, u$ and $c$ measures can be considered valid measures of $P, U$, and $C$ respectively if the estimated coefficients $\beta_{1}, \beta_{2}$, and $\beta_{3}$ satisfy $\beta_{1}=\beta_{2}=\beta_{3}=1$. Since our model equation $Y=P \cdot U \cdot C$ is novel to the literature, this kind of validity test has not been tried yet.

Having a valid power measure would allow to analyze managerial preferences more generally, not only their preferences for money. Since power is defined as an opportunity to make happen whatever the power holder wants to happen, one can search e.g. for different decision patterns across executives. If companies with powerful CEOs follow pattern A, while companies with less powerful CEOs follow pattern B, this would imply that CEOs have a preference for pattern A. For example, if we observe that firms with more powerful CEOs tend to have their own corporate planes, while the others don't, the implication would be that CEOs have a preference for planes that is strong enough to induce them to use their power to obtain one. The opposite is also true. If we do not observe different patterns across power categories of CEOs, this would imply that CEOs don't care for the pattern. Just assume that we would observe that more powerful CEOs have no more golden parachutes than less powerful ones. This would not imply that the powerful CEOs have no power, it would imply that they don't care enough for golden parachutes. So with a valid power measure at hand, there are interesting opportunities to explore the preferences of CEOs.

\subsection{Measure construction}

The second avenue we suggest is not to validate empirical power measures but to compute one. If power usage $U$, cake size $C$, and compensation $Y$ are known, our above equation can be solved for power $P=Y /(U \cdot C)$. If $U, C$ and $Y$ are known, one does not have to measure power via some empirically observable indicator, one can simply compute it. The idea to observe compensation to find out who has power is not new, though. More than 20 years ago, Hambrick and Finkelstein (1995, p. 175) noted: "Namely, to observe CEO pay is to observe in an indirect but very tangible way the fundamental governance process in large corporations. Who has power?" What Hambrick and Finkelstein suggested here is that, from a measurement point of view, pay is not only correlated with power, but it is power. From our paper's point of view, their suggestion is correct, although observation of compensation alone is not sufficient, as information on $C$ and $U$ are also needed. 


\subsection{Testing for inclinations to use power}

The third avenue we suggest is to use the equation $Y=P \cdot U \cdot C$ as the theoretical basis for research on individuals' inclinations to actually use the power they have. This could eventually be done in experimental settings, where compensation $Y$ can be observed and power $P$ and cake size $C$ can be adequately controlled. If one has information on these three variables, one could solve the above equation and compute each individual's $U$-value to find out who uses their power and to what extent. We actually found an interesting paper documenting such an experiment. This was conducted by Dorff (2005), who tried to prove the existence of a relationship between power and pay. As argued above, this is impossible. So what he actually did was to test the degree of power usage. In his experiment, the power of students playing the roles of CEOs was varied over time. In the first round of the experiment, directors set CEO pay and were allowed to set their own pay within a given range. In the second round, directors still had to set CEO pay but were not allowed to set their own pay anymore. In round 2, power of CEOs over directors was increased as compared to round 1, by giving CEOs the opportunity to set directors' pay or even to fire them, resulting in financial losses for directors. This variation of power fitted neatly within the definition of power suggested above: CEOs in round 2 in the experiment were given the additional power to reward and the additional power to punish. It can therefore readily be accepted that the variation of power was implemented correctly. In fact, compensation of CEOs in the second round was significantly higher when compared to the first round. Dorff (2005, p. 290) concluded that "power over directors dramatically impacted executive compensation".

Returning to the mathematical representation of our definition, $Y=P \cdot U \cdot C$, it is obvious that power-based pay $Y$ must increase if one or more of the variables $P, U$, and $C$ increase while the others remain constant, or at least do not decrease enough to offset the effect of this variable or these variables that increase. Since the size of the cake $C$ was held constant over the course of the experiment, the increase in pay could only be due to an increase in power $P$ or an increase in power usage $U$. Since power was in fact increased, Dorff's finding implied that the degree of power usage at least did not decrease enough to offset the effect of rising power. This was not expected, since the CEOs in round one were also the CEOs in round two. It can rather be assumed that the degree of power usage is a kind of personal characteristic that is constant at least over the short term. A high degree of power usage could eventually be interpreted as indicative of a rather egoistic agent, while a low degree indicates altruistic motivations.

If there had been a decline in compensation from round one to round two, the only explanation would have been that the degree of power usage had declined. So if $U$ is also assumed to be constant, compensation must increase from round one to round two by definition. In fact, one result of Dorff's experiment was that the participating students did not become more altruistic over the course of the experiment. Dorff (2005, p. 289) had seen the altruism problem himself when he noted: "Although the risk of excessive altruism existed, it did not appear to manifest. In both phases, most directors and executives acted to maximize their own income, 
necessarily at shareholders' expense. If altruistic impulses toward fellow student shareholders blunted participants' self-interest, the effect is not apparent from the data."

Dorff thus admitted that the positive correlation between power and pay was at risk only in a population of altruists. The opposite is also true: the positive correlation only proved that participants were not altruists. It did not prove that power drove pay. The truly interesting result of Dorff's experiment was therefore not that compensation rose from round one to round two. The truly interesting result was that there was a significant variation of compensation across individuals (Dorff 2005, p. 277). Since all have been given the same amount of power over the same amount of money, the variation of compensation across individuals indicates that there is a significant variation of power usage. The experiment of Dorff is thus a kind of blueprint for experiments to test for individuals' inclinations to use the power given to them. Of course, Dorff's result is just the result of one experiment. But should we find more evidence on differing inclinations to use power across individuals, these inclinations can obviously not be ignored in the empirical settings we discussed above.

Of course, such an approach cannot only be employed to find out whether or not there are differences across individuals. The more interesting question would be what determines these differences. One could thus test for effects of individual characteristics or e.g. cultural background. We also see interesting designs in the tradition of behavioral economics. For example, it could be tested whether there are framing or labeling effects. Playing the role of a CEO who can eventually exploit shareholders may induce other behaviors than playing the role of a dentist who can eventually exploit patients. The broader question thus would be under what circumstances power would be employed and under which it wouldn't.

It is worth noting that the three avenues we suggested above have one important property in common. All three avenues employ compensation as an independent variable. As outlined above, treating power as an independent variable cannot yield meaningful results.

\section{Summary and outlook}

As demonstrated above, the central "hypothesis" of the managerial power approach i.e., that there is a positive impact of power on compensation is correct. But it is tautologically correct since this impact follows directly form the definition of power. Since it is tautologically correct, it cannot be tested empirically. There is no and there cannot be any empirical evidence demonstrating that power impacts on pay. This impact follows on solely from the very definition of power. Not even the marginal effect of power on compensation can be estimated.

Based on the arguments developed here, it is possible to characterize the dispute between advocates and antagonists of the MPA partially as a mock battle. This is because some of the aspects of the power-pay relationship discussed above have been ignored so far.

For example, critics of the MPA pointed out that CEO compensation increased considerably throughout the 1990s, while managerial power supposedly declined. 
Indeed, boards became more independent and compensation disclosure rules tightened throughout this period (Murphy 2002, p. 852). Yet according to the logic laid out by the MPA, both of these regulatory measures should have limited managerial power, resulting in the decline of compensation. Since it was observed that compensation in fact rose, critics argued that the MPA could not be correct.

In turn, proponents of the MPA defended their position by arguing that other changes in the corporate governance setting may have created new sources of managerial power. For example, anti-takeover defenses were strengthened, easing the concern of managers and directors over the threat of a hostile takeover (Bebchuk and Fried 2004, p. 72). Furthermore, the positive performance of firms during the 1990s, combined with the increased use of performance-related pay, especially stock options, led to favorable compensation arrangements for managers (Bebchuk and Fried 2004, p. 72). Thus, managers were able to use their power to obtain option plans that served their interests and led to a decoupling of pay and performance (Bebchuk and Fried 2004, p. 137 and p. 179).

In light of the specification of the relationship between power and pay derived above, this debate is partially misguided. Since power-based pay does not depend on power alone, but also on power usage and the size of the cake, highly relevant factors have been ignored in this debate. Irrespective of whether managerial power over the 1990s increased or not, power-based pay could have risen anyway. This could be due to bigger cakes in the 1990s or due to a higher degree of power usage even if power would have declined in that era.

One (rough) way of measuring the change in cake sizes would be simply to look at stock market performance. Over the 1990s, the Dow Jones Industrial Average climbed from 2748.72 on January 2, 1990 to $11,452.86$ on December 30, 1999. ${ }^{1}$ This increase by more than 300 percent may well indicate that the cakes had grown much larger. So even if managerial power had declined in the course of that decade, power-based pay may still have increased considerably due to the huge increase in cake sizes.

What is more, the degree of power usage may also have risen. Bowles (2008) stated that the emphasis of individual incentives may crowd out pro-social behavior. Managers in the 1990s may just have changed their attitudes towards power usage and simply made more use of the power they had than they had done before. A rising inclination to use power might just have outweighed the decline in power that actually might have occurred.

Determining which of these speculations has the highest merits is an empirical question that remains open. Measures of power, power usage and cake size are required in order to draw conclusions about the "success" of corporate governance reforms aimed at limiting managerial power.

The arguments developed here may also be valuable for international comparisons. As Hofstede (2007) suggested, western societies place a higher emphasis on

\footnotetext{
1 The detailed development of DJI from Jan. 2, 1990 to Dec. 30, 1999 was retrieved from: https://finan ce.ya-hoo.com/quote/\%5EDJI/history?period $1=631148400 \&$ period $2=946594800 \&$ interval $=1 \mathrm{~d} \&$ filte $\mathrm{r}=$ history \&frequency=1d [July 21, 2017].
} 
individualism than eastern societies, which tend to favor collectivism. In a society of individualists, people are expected to focus on themselves and maybe, perhaps, their family and friends. Collectivism, in contrast, stands for a society in which people are integrated into strong, cohesive in-groups. Hofstede ascertained that western countries all scored above average on individualism, with the U.S. being identified as the most individualistic country. Asian countries all scored below average on individualism, and scored high on collectivism. Furthermore, he pointed out that in most cases, in-groups included extended families, but in Japan the employer can also play part of this in-group role (Hofstede 2007, p. 416; Hofstede et al. 2010, p. 94). These closer ties may account for the fact that CEOs earning significantly more than workers further down in the hierarchy is considered to be more acceptable in western societies than in eastern ones. In 2003, a conservative estimate of the average pay of a CEO in Japan was $\$ 456,937$, while a U.S. counterpart earned $\$ 2,249,080$. The ratio between CEO and worker pay was 9:1 in Japan and 45:1 in the U.S. Other figures using a broader definition of compensation estimated the U.S. pay ratio at 240:1 (Burton and Weller 2005). The gap between CEO pay in Japan and the U.S. has grown slightly in recent years. In 2009, average Japanese CEO compensation climbed up to $\$ 580,000$ while U.S. CEO compensation rose to $\$ 3,500,000$. One conclusion that eventually could be drawn from these figures is that CEOs in western societies may have more of an inclination to use their power than those in eastern societies. In this case, perhaps Japanese managers do not earn less than their U.S. counterparts because they have different jobs or less power, but rather because they simply make less use of their power. In fact, Tosi and Greckhamer (2013) found a positive effect of individualism on total CEO compensation.

We have demonstrated that the existence of a positive effect of power on compensation cannot be proven empirically. Empirical studies in this field have done nothing more, and nothing less, than trying to identify and validate possible empirical measures of power. However, power usage and the size of the cake have not been adequately accounted for so far. Results up to this point thus could be subject to a severe omitted variables problem. It should therefore be worthwhile to employ the empirical procedures described above that control for $U$ and $C$. When this is done appropriately, it should be possible to validate and/or construct empirical measures of power.

A valid power measure can then be used to analyze managerial preferences more generally, not only their preferences for money. Since power is defined as an opportunity to make happen whatever the power holder wants to happen, one can search e.g. for different decision patterns across executives. With a valid power measure at hand, there are interesting opportunities to explore the preferences of CEOs.

Based on the arguments developed in this paper, it is also possible to design experimental settings to test for differences in individual inclinations to actually make use of power. We see a wide array of possible sources of interpersonal differences. It could be tested whether differences depend on personal characteristics, cultural background, or even the framing and/or labeling of the experiment.

For those interested explicitly in executive compensation there is also much worthwhile work that remains to be done. In this paper we have discussed power driven compensation alone. But neither we nor the advocates of the MPA suggest 
that all compensation is driven by power alone. This implies that procedures must be developed to separate the power driven part of compensation from the that part that is determined by other factors like e.g. human capital, forces of demand and supply, firm characteristics, and so on.

Open Access This article is distributed under the terms of the Creative Commons Attribution 4.0 International License (http://creativecommons.org/licenses/by/4.0/), which permits unrestricted use, distribution, and reproduction in any medium, provided you give appropriate credit to the original author(s) and the source, provide a link to the Creative Commons license, and indicate if changes were made.

\section{Appendix 1}

Let us look at two artificial samples of executives' compensation. Let us label these two samples simply as "Sample 1" and "Sample 2". Since both samples are artificial, we can exclude the possibility of any measurement errors or other mistakes. If there are no measurement errors, power based compensation Y must exactly meet the condition $Y=P \cdot U \cdot C$. We assume in our artificial samples that this is the case for each single executive. For both samples we compare an ex ante situation with an ex post situation. The difference between both situations in the two samples is just that executives in the ex post situation each have 0.05 units of power more than they had in the ex-ante situations. The following table displays the data of both samples in the ex-ante and ex-post situations.

\section{Sample 1}

\begin{tabular}{|c|c|c|c|c|c|c|c|c|}
\hline \multirow[t]{2}{*}{ Executive $j$} & \multicolumn{4}{|c|}{ ex-ante } & \multicolumn{4}{|c|}{ ex-post } \\
\hline & $P$ & $U$ & $C$ & $Y$ & $P$ & $U$ & $C$ & $Y$ \\
\hline 1 & 0.12 & 0.7 & 1800 & 151.20 & 0.17 & 0.7 & 1800 & 214.20 \\
\hline 2 & 0.18 & 0.6 & 1500 & 162.00 & 0.23 & 0.6 & 1500 & 207.00 \\
\hline 3 & 0.39 & 0.2 & 800 & 62.40 & 0.44 & 0.2 & 800 & 70.40 \\
\hline 4 & 0.88 & 0.1 & 220 & 19.36 & 0.93 & 0.1 & 220 & 20.46 \\
\hline 5 & 0.42 & 0.3 & 250 & 31.50 & 0.47 & 0.3 & 250 & 35.25 \\
\hline
\end{tabular}

\section{Sample 2}

\begin{tabular}{|c|c|c|c|c|c|c|c|c|}
\hline \multirow[t]{2}{*}{ Executive $j$} & \multicolumn{4}{|c|}{ ex-ante } & \multicolumn{4}{|c|}{ ex-post } \\
\hline & $P$ & $U$ & $C$ & $Y$ & $P$ & $U$ & $C$ & $Y$ \\
\hline 1 & 0.12 & 0.3 & 1000 & 36.00 & 0.17 & 0.3 & 1000 & 51.00 \\
\hline 2 & 0.18 & 0.4 & 500 & 36.00 & 0.23 & 0.4 & 500 & 46.00 \\
\hline 3 & 0.39 & 0.5 & 800 & 156.00 & 0.44 & 0.5 & 800 & 176.00 \\
\hline 4 & 0.88 & 0.9 & 2000 & 1584.00 & 0.93 & 0.9 & 2000 & 1674.00 \\
\hline 5 & 0.42 & 0.7 & 1400 & 411.60 & 0.47 & 0.7 & 1400 & 460.60 \\
\hline
\end{tabular}


If we look at the scatterplots and regression lines for the two samples ex ante and ex post, we obtain the following figures:
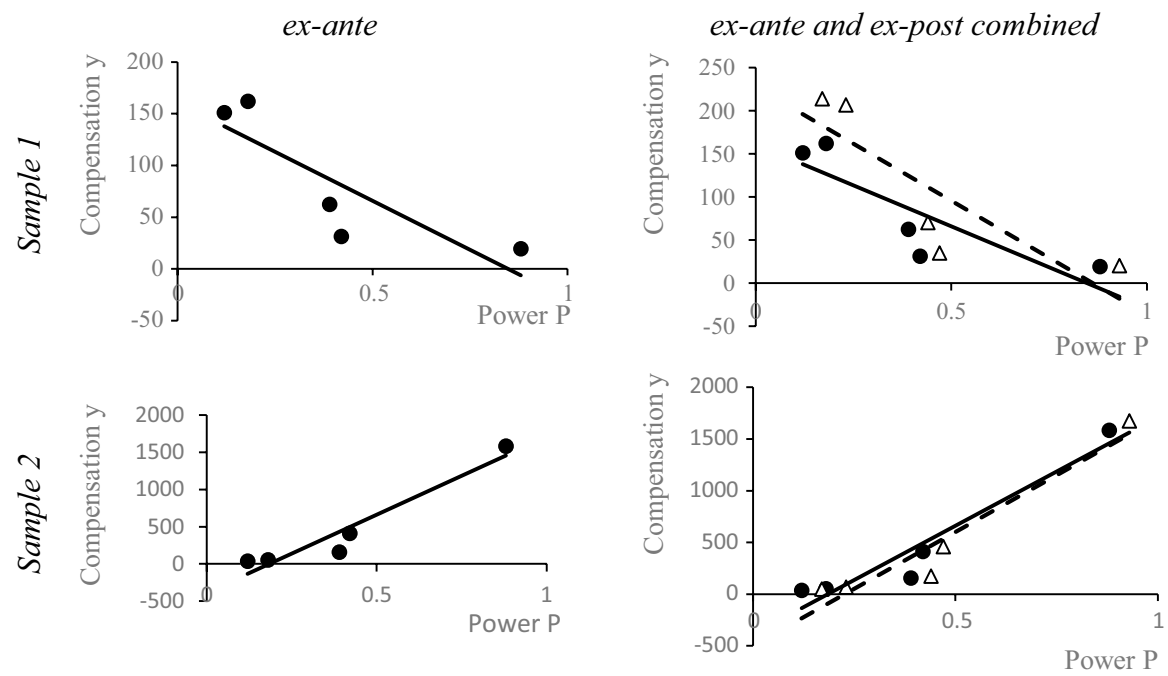

Notes: Ex-ante data is represented by solid dots and solid regression lines and expost data by triangles and dashed regression lines.

In Sample 1 we find negative associations between power and compensation, in Sample 2 we find positive associations. But both associations are based on spurious correlations due to an omitted variable bias. The effect of increasing power on compensation is not represented by the slopes of any of these regression lines but by the shift from the solid to the dashed regression lines. The slopes are meaningless. Already and only by definition, there must be a positive impact of power on compensation, everything else kept constant.

\section{Appendix 2}

See Table 3. 
Table 3 Studies included in analysis

Studies with variable "insider ratio"

Balkin et al. (2000)

Grossman and Canella (2006)

Boyd (1994)

He (2008)

Carr (1997)

Hebner and Kato (1997)

Core et al. (1999)

Ghosh and Sirmans (2005)

Staw and Epstein (2000)

Westphal and Zajac (1995)

Grinstein and Hribar (2004)

Studies with variable "Percentage of outside directors"

Angbazo and Narayanan (1997)

Harris and Helfat (1997)

Berrone and Gomez-Mejia (2009)

Lambert et al. (1993)

Conyon and Peck (1998)

Cordeiro and Veliyath (2003)

Cyert et al. (2002)

Larcker et al. (2005)

Main et al. (1995)

Mangel and Singh (1993)

David et al. (1998)

Noguera and Highfield (2006)

Studies with variable "Board size"

Angbazo and Narayanan (1997)

He (2008)

Core et al. (1999)

Larcker et al. (2005)

Cyert et al. (2002)

Ghosh and Sirmans (2005)

Grinstein and Hribar (2004)

Harris and Helfat (1997)

Studies with variable "CEO ownership"

Attaway (2000)

Jalbert et al. (2007)

Berrone and Gomez-Mejia (2009)

Bliss and Rosen (2001)

Khan et al. (2005)

Kim (2010)

Carpenter et al. (2001)

Lambert et al. (1993)

Coombs and Gilley (2005)

Mangel and Singh (1993)

Core et al. (1999)

Miller et al. (2002)

Cyert et al. (2002)

Noguera and Highfield (2006)

Daily et al. (1998)

Davila and Penalva (2006)

Riahi-Belkaoui and Pavlik (1993)

Roulstone (2003)

Davila and Venkatachalam (2004)

Sanders and Carpenter (1998)

Finkelstein and Boyd (1998)

Finkelstein and Hambrick (1989)

Sapp (2008)

Talmor and Wallace (2001)

Ghosh and Sirmans (2005)

van der Laan (2010)

He (2008)

Studies with variable "CEO duality"

Angbazo and Narayanan (1997)

Wright and Kroll (2002)

Berrone and Gomez-Mejia (2009)

Harjoto and Mullineuax (2003)

Boyd (1994)

He (2008)

Main et al. (1995)

Conyon and Peck (1998)

Noguera and Highfield (2006)

Cordeiro and Veliyath (2003)

O'Reilly and Main (2010)

Core et al. (1999)

Otten and Heugens (2008) 
Table 3 (continued)

Cyert et al. (2002)

David et al. (1998)

Elhagrasey et al. (1999)

Ghosh and Sirmans (2005)

Gomez-Mejia et al. (2003)

Gray and Canella (1997)

Grinstein and Hribar (2004)

Grossman and Canella (2006)

Studies with variable "CEO tenure"

Attaway (2000)

Balkin et al. (2000)

Bebchuk et al. (2010)

Berrone and Gomez-Mejia (2009)

Campbell et al. (2007)

Carpenter et al. (2001)

Chhaochharia and Grinstein (2009)

Conyon et al. (2009)

Coombs and Gilley (2005)

Cordeiro and Veliyath (2003)

Cyert et al. (2002)

Daily et al. (1998)

David et al. (1998)

Davila and Venkatachalam (2004)

Deckop (1988)

Elhagrasey et al. (1999)

Finkelstein and Boyd (1998)

Finkelstein and Hambrick (1989)

Geiger and Cashen (2007)

Gomez-Mejia et al. (2003)

Gray and Canella (1997)

Grossman and Canella (2006)

Harjoto and Mullineuax (2003)

$\mathrm{He}$ (2008)

Hebner and Kato (1997)

Henderson and Fredrickson (1996)

Studies with variable "institutional investors"

Almazan et al. (2005)

Angbazo and Narayanan (1997)

Cordeiro and Veliyath (2003)

Core et al. (1999)

Cyert et al. (2002)

Daily et al. (1998)

David et al. (1998)

Ghosh and Sirmans (2005)
Renneboog and Zhao (2011)

Sanders and Carpenter (1998)

Sapp (2008)

Staw and Epstein (2000)

Sung and Swan (2008)

Tien et al. (2014)

van Essen et al. (2015)

Westphal and Zajac (1995)

Hill and Phan (1991)

Hogan and McPheters (1980)

Jalbert et al. (2007)

Kato and Rockel (1992)

Kim (2010)

Larcker et al. (2005)

Main et al. (1995)

Mangel and Singh (1993)

Miller et al. (2002)

Newman and Mozes (1999)

O'Reilly and Main (2010)

Renneboog and Zhao (2011)

Sanders and Carpenter (1998)

Sapp (2008)

Sigler (2003)

Smith and Swan (2008)

Staw and Epstein (2000)

Sung and Swan (2008)

Talmor and Wallace (2001)

Tien et al. (2014)

van der Laan (2010)

van Essen et al. (2015)

Wade et al. (2006)

Westphal and Zajac (1995)

Wright and Kroll (2002)

Gomez-Mejia et al. (2003)

Khan et al. (2005)

Mangel and Singh (1993)

Noguera and Highfield (2006)

van Essen et al. (2015)

Wade et al. (2006)

Winfrey and Logan (1998) 


\section{References}

Almazan, A., Hartzell, J. C., \& Starks, L. T. (2005). Active institutional shareholders and costs of monitoring: Evidence from executive compensation. Financial Management, 34(4), 5-34.

Angbazo, L., \& Narayanan, R. (1997). Top management compensation and the structure of the board of directors in commercial banks. Review of Finance, 1(2), 239-259.

Ataay, A. (2018). Performance sensitivity of executive pay: The role of ownership structure, board leadership structure and board characteristics. Economic Research, 31(1), 1152-1168.

Attaway, M. C. (2000). A study of the relationship between company performance and CEO compensation. American Business Review, 18(1), 77-85.

Balkin, D. B., Markman, G. D., \& Gomez-Mejia, L. R. (2000). Is CEO pay on high-technology firms related to innovation? Academy of Management Journal, 43(6), 1118-1129.

Baysinger, B., \& Hoskisson, R. E. (1990). The composition of boards of directors and strategic control: Effects on corporate strategy. The Academy of Management Review, 15, 72-87.

Bebchuk, L. A., \& Fried, J. M. (2004). Pay without performance: The unfulfilled promise of executive compensation. Cambridge, MA: Harvard University Press.

Bebchuk, L. A., Fried, J. M., \& Walker, D. I. (2002). Managerial power and rent extraction in the design of executive compensation. University of Chicago Law Review, 69, 751-846.

Bebchuk, L. A., Grinstein, Y., \& Peyer, U. (2010). Lucky CEOs and lucky directors. Journal of Finance, 65, 2363-2401.

Becker, B., Cronqvist, H., \& Fahlenbrach, R. (2011). Estimating the effects of large shareholders using a geographic instrument. Journal of Financial and Quantitative Analysis, 46, 907-942.

Berrone, P., \& Gomez-Mejia, L. R. (2009). Environmental performance and executive compensation: An integrated agency-institutional perspective. Academy of Management Journal, 52(1), 103-126.

Bertrand, M., \& Mullainathan, S. (2000). Agents with and without principals. American Economic Review, 90, 203-208.

Bertrand, M., \& Mullainathan, S. (2001). Are CEOs rewarded for Luck? The ones without principals are. Quarterly Journal of Economics, 116, 901-932.

Bliss, R. T., \& Rosen, R. J. (2001). CEO compensation and bank mergers. Journal of Financial Economics, 61(1), 107-138.

Borokhovic, K. A., Brunarski, K. R., \& Parrino, R. (1997). CEO contracting and anti-takeover amendments. Journal of Finance, 52, 1495-1517.

Bowles, S. (2008). Policies designed for self-interested citizens may undermine the "moral sentiments": Evidence from economic experiments. Science, 320, 1605-1609.

Boyd, B. K. (1994). Board control and CEO compensation. Strategic Management Journal, 15, 335-344.

Brookman, J., \& Thistle, P. D. (2009). CEO tenure, the risk of termination and firm value. Journal of Corporate Finance, 15, 331-344.

Burton, J., \& Weller, C. (2005). Supersize this: How CEO pay took off while America's middle class struggled. Washington, DC: Center for American Progress.

Campbell, K., Johnston, D., Sefcik, S. E., \& Soderstrom, N. (2007). Executive compensation and nonfinancial risk: An empirical examination. Journal of Accounting and Public Policy, 26(4), 436-462.

Carpenter, M. A., Sanders, G., \& Gregersen, H. B. (2001). Bundling human capital with organizational context: The impact of international assignment experience on multinational firm performance and CEO pay. Academy of Management Journal, 44(3), 493-511.

Carr, L. L. (1997). Strategic Determinants of Executive Compensation in Small Publicly Traded Firms. Journal of Small Business Management, 35(2), 1-12.

Cheng, S. J. (2008). Board size and the variability of corporate performance. Journal of Financial Economics, 87, 157-176.

Cheng, S. J., \& Indjejikian, R. J. (2009). The market for corporate control and CEO compensation: Complements or substitutes? Contemporary Accounting Research, 26, 701-728.

Chhaochharia, V., \& Grinstein, Y. (2009). CEO compensation and board structure. Journal of Finance, 64, 231-261.

Chhaochharia, V., Kumar, A., \& Niessen-Ruenzi, A. (2012). Local investors and corporate governance. Journal of Accounting and Economics, 54, 42-67.

Clenfield, J. (2010). In Japan, underpaid—and loving it. Business Week. http://www.bloomberg.com/bw/ magazine/content/10_28/b4186014341924.htm. Accessed July 1, 2017. 
Conyon, M. J., \& Peck, S. I. (1998). Board control, remuneration committees, and top management compensation. Academy of Management Journal, 41(2), 146-157.

Conyon, M. J., Peck, S. I., \& Sadler, G. V. (2009). Compensation consultants and executive pay: Evidence from the United States and the United Kingdom. Academy of Management Perspectives, 23(1), 43-55.

Coombs, J. E., \& Gilley, K. M. (2005). Stakeholder management as a predictor of CEO compensation: Main effects and interactions with financial performance. Strategic Management Journal, 26(9), $827-840$.

Cordeiro, J. J., \& Veliyath, R. (2003). Beyond pay of performance: A panel study of the determinants of CEO compensation. American Business Review, 21(1), 56-66.

Core, J. E., Guay, W., \& Larcker, D. F. (2008). The power of the pen and executive compensation. Journal of Financial Economics, 88, 1-25.

Core, J. E., Guay, W., \& Thomas, R. (2005). Is U.S. CEO compensation inefficient pay without performance? Michigan Law Review, 103, 1142-1185.

Core, J. E., Holthausen, R. W., \& Larcker, D. F. (1999). Corporate governance, chief executive officer compensation, and firm performance. Journal of Financial Economics, 51, 371-406.

Cyert, R. M., Kang, S. H., \& Kumar, P. (2002). Corporate governance, takeovers, and top-management compensation: Theory and evidence. Management Science, 48, 453-469.

Dahl, R. A. (1957). The concept of power. Behavioral Science, 2, 201-215.

Daily, C. M., Johnson, J. L., Ellstrand, A. E., \& Dalton, D. R. (1998). Compensation committee composition as a determinant of CEO compensation. Academy of Management Journal, 41(2), 209-220.

David, P., Kochhar, R., \& Levitas, E. (1998). The effect of institutional investors on the level and mix of CEO compensation. Academy of Management Journal, 41, 200-208.

Davila, A., \& Penalva, F. (2006). Governance structure and the weighting of performance measures in CEO compensation. Review of Accounting Studies, 11(4), 463-493.

Davila, A., \& Venkatachalam, M. (2004). The relevance of non-financial performance measures for CEO compensation: Evidence from the airline industry. Review of Accounting Studies, 9(4), 443-464.

Deckop, J. R. (1988). Determinants of chief executive officer compensation. Industrial and Labor Relations Review, 41(2), 215-226.

Dorff, M. B. (2005). Does one hand wash the other? Testing the managerial power and optimal contracting theories of executive compensation. Journal of Corporation Law, 30, 255-307.

Eisenberg, T., Sandgren, S., \& Wells, M. T. (1998). Larger board size and decreasing firm value in small firms. Journal of Financial Economics, 48, 35-54.

Elhagrasey, G. M., Harrison, J. R., \& Buchholz, R. A. (1999). Power and pay: The politics of CEO compensation. Journal of Management and Governance, 2(4), 309-332.

Fahlenbrach, R. (2009). Shareholder rights, boards, and CEO compensation. Review of Finance, 13, 81-113.

Finkelstein, S., \& Boyd, B. K. (1998). How much does the CEO matter? The role of managerial discretion in the setting of CEO compensation. Academy of Management Journal, 41(2), 179-199.

Finkelstein, S., \& Hambrick, D. C. (1989). Chief executive compensation: A study of the intersection of markets and political processes. Strategic Management Journal, 10, 121-134.

Fong, E. A., Misangyi, V. F., \& Tosi, H. L. (2010). The effect of CEO pay deviations on CEO withdrawal, firm size, and firm profits. Strategic Management Journal, 31, 629-651.

French, J. R. P., \& Raven, B. H. (1959). The bases of social power. In D. Cartwright (Ed.), Studies in social power (pp. 150-167). Ann Arbor, MI: Institute for Social Research.

Geiger, S. W., \& Cashen, L. H. (2007). Organizational size and CEO compensation: The moderating effect of diversification in downscoping organizations. Journal of Managerial Issues, 19(2), $233-252$.

Ghosh, C., \& Sirmans, C. F. (2005). On REIT CEO compensation: Does board structure matter? The Journal of Real Estate Finance and Economics, 30(4), 397-428.

Gomez-Mejia, L. R., Larraza-Kintana, M., \& Makri, M. (2003). The determinants of executive compensation in family-controlled public corporations. Academy of Management Journal, 46(2), 226-237.

Gray, S. R., \& Canella, A. A., Jr. (1997). The role of risk in executive compensation. Journal of Management, 23(4), 517-540.

Grinstein, Y., \& Hribar, P. (2004). CEO compensation and incentives: Evidence from M\&A bonuses. Journal of Financial Economics, 73, 119-143.

Grossman, W., \& Canella, A. A., Jr. (2006). The impact of strategic persistence on executive compensation. Journal of Management, 32(2), 257-278. 
Hallock, K. (1997). Reciprocally interlocking boards of directors and executive compensation. Journal of Financial and Quantitative Analysis, 32, 331-344.

Hambrick, D. C., \& Finkelstein, S. (1995). The effects of ownership structure on conditions at the top: The case of CEO pay raises. Strategic Management Journal, 16, 175-193.

Harjoto, M. A., \& Mullineuax, D. J. (2003). CEO compensation and the transformation of banking. The Journal of Financial Research, 26(3), 341-354.

Harris, D., \& Helfat, C. (1997). Specificity of CEO human capital and compensation. Strategic Management Journal, 18(11), 895-920.

Harsanyi, J. C. (1964). Measurement of social power. In M. Shubik (Ed.), Game theory and related approaches to social behavior (pp. 183-206). New York: Wiley.

Hartzell, J., \& Starks, L. T. (2003). Institutional Investors and Executive Compensation. Journal of Finance, 58, 2351-2374.

He, L. (2008). Do founders matter? A study of executive compensation, governance structure and firm performance. Journal of Business Venturing, 23(3), 257-279.

Hebner, K. J., \& Kato, T. (1997). Insider trading and executive compensation: Evidence from the U.S. and Japan. International Review of Economics and Finance, 6(3), 223-237.

Henderson, A. D., \& Fredrickson, J. W. (1996). Information-processing demands as a determinant of CEO compensation. Academy of Management Journal, 39(3), 575-606.

Hill, C. W. L., \& Phan, P. (1991). CEO tenure as a determinant of CEO pay. Academy of Management Journal, 34, 707-717.

Hofstede, G. (2007). Asian management in the 21st century. Asia Pacific Journal of Management, 24, 411-420.

Hofstede, G., Hofstede, G. J., \& Minkov, M. (2010). Cultures and organizations: Software of the mind. New York: McGraw-Hill.

Hogan, T. D., \& McPheters, L. R. (1980). Executive Compensation: Performance versus personal characteristics. Southern Economic Journal, 46(4), 1060-1068.

Jalbert, T., Chan, C., Jalbert, M., \& Landry, S. P. (2007). The interrelationship of CEO nationality with financial management, firm performance, and CEO compensation. Journal of Diversity Management, 2(2), 7-24.

Kaplan, S. N. (2008). Are U.S. CEOs overpaid? Academy of Management Perspectives, 22(2), 5-20.

Kato, T., \& Rockel, M. (1992). Experiences, credentials, and compensation in the Japanese and U.S. managerial labor markets: Evidence from new micro data. Journal of the Japanese and International Economies, 6(1), 30-51.

Khan, R., Dharwadkar, R., \& Brandes, P. (2005). Institutional ownership and CEO compensation: A longitudinal examination. Journal of Business Research, 58, 1078-1088.

Kim, K. (2010). Blockholder monitoring and the efficiency of pay-performance benchmarking. Journal of Corporate Finance, 16, 748-766.

Korkeamaki, T., Liljeblom, E., \& Pasternack, D. (2017). CEO power and matching leverage preferences. Journal of Corporate Finance, 45, 19-30.

Lambert, R. A., Larcker, D. F., \& Weigelt, K. (1993). The structure of organizational incentives. Administrative Science Quarterly, 38, 438-461.

Larcker, D. F., Richardson, S. A., Seary, A. J., \& Tuna, I. (2005). Back door links between directors and executive compensation. The Wharton School-University of Pennsylvania working paper.

Main, B. G. M., O'Reilly, C. A., III, \& Wade, J. (1995). The CEO, the board of directors and executive compensation: Economic and psychological perspectives. Industrial and Corporate Change, 4(2), 293-332.

Malmendier, U., \& Tate, G. (2009). Superstar CEOs. Quarterly Journal of Economics, 124, 1593-1638.

Mangel, R., \& Singh, H. (1993). Ownership structure, board relationships and CEO compensation in large US corporations. Accounting and Business Research, 23(91A), 339-350.

Miller, J. C., Wiseman, R. M., \& Gomez-Mejia, L. R. (2002). The fit between CEO compensation design and firm risk. Academy of Management Journal, 45(4), 745-756.

Mizruchi, M. S. (1983). Who Controls whom? An examination of the relation between management and boards of directors in large corporations. Academy of Management Review, 8(4), 426-435.

Murphy, K. J. (1986). Incentives, learning, and compensation: A theoretical and empirical investigation of managerial labor contracts. RAND Journal of Economics, 17(1), 59-76.

Murphy, K. J. (2002). Explaining executive compensation: Managerial power versus the perceived cost of stock options. University of Chicago Law Review, 69, 847-869. 
Newman, H. A., \& Mozes, H. A. (1999). Does the composition of the compensation committee influence CEO compensation practices? Financial Management, 28(3), 41-53.

Noguera, M. C., \& Highfield, M. J. (2006). CEO incentive-based compensation and REIT performance. Mississippi State University working paper.

O'Reilly, C. A., \& Main, B. G. M. (2010). Economic and psychological perspectives on CEO compensation: A review and synthesis. Industrial and Corporate Change, 19, 675-712.

Oppenheim, F. E. (1978). 'Power' revisited. Journal of Politics, 40, 589-608.

Otten, J., \& Heugens, P. (2008). Extending the managerial power theory of executive pay: A cross national test. Erasmus University Rotterdam working paper ERS-2007-090-ORG.

Qian, M., Sun, P.-W., \& Yu, B. (2018). Top managerial power and stock price efficiency: Evidence from China. Pacific-Basin Finance Journal, 47, 20-38.

Raven, B. H. (1965). Social influence and power. In I. D. Steiner \& M. Fishbein (Eds.), Current studies in social psychology (pp. 371-382). New York: Holt, Rinehart, Winston.

Raven, B. H. (2008). The bases of social power and the power/interaction model of interpersonal influence. Analyses of Social Issues and Public Policy, 8, 1-22.

Renneboog, L., \& Zhao, Y. (2011). Us knows us in the UK: On director networks and CEO compensation. Journal of Corporate Finance, 17, 1132-1157.

Riahi-Belkaoui, A., \& Pavlik, E. (1993). Effects of ownership structure, firm performance, size and diversification strategy on CEO compensation: A path analysis. Managerial Finance, 19(2), 33-54.

Roulstone, D. T. (2003). The relation between insider-trading restrictions and executive compensation. Journal of Accounting Research., 42(3), 525-551.

Sanders, G., \& Carpenter, M. A. (1998). Internationalization and firm governance: The roles of CEO compensation, top team composition, and board structure. Academy of Management Journal, 41(2), 158-178.

Sapp, S. G. (2008). The impact of corporate governance on executive compensation. European Financial Management, 14, 710-746.

Shin, T. (2016). Fair pay or power play? Pay equity, managerial power, and compensation adjustment for CEOs. Journal of Management, 42, 419-448.

Sigler, K. J. (2003). CEO compensation and healthcare organisation performance. Management Research News, 26(6), 31-38.

Smith, G. S., \& Swan, P. L. (2008). The road to riches: CEO incentives and firm performance. The University of New South Wales working paper.

Staw, B. M., \& Epstein, L. D. (2000). What bandwagons bring: Effects of popular management techniques on corporate performance, reputation, and CEO pay. Administrative Science Quarterly, 45(3), 523-556.

Sung, J., \& Swan, P. L. (2008). Executive pay, talent and firm size. The University of New South Wales working paper-21st Australasian finance and banking conference 2008.

Talmor, E., \& Wallace, J. S. (2001). A unified analysis of executive pay: The case of the financial sector. London Business School working paper subject area no. 22.

Tien, C., Chen, C.-N., \& Chuang, C.-M. (2014). A study of CEO power, pay structure, and firm performance. Journal of Management and Organization, 19(4), 424-453.

Tosi, H. L., \& Greckhamer, T. (2013). Culture and CEO compensation. Organization Science, 15(6), $657-670$.

van der Laan, G. (2010). CEO pay as a reflection of power or performance: An empirical test for the Netherlands. Journal of Strategy and Management, 3(2), 157-173.

van Essen, M., Otten, J., \& Carberry, E. J. (2015). Assessing managerial power theory: A meta-analytic approach to understanding the determinants of CEO compensation. Journal of Management, 49, 164-202.

Wade, J. B., O'Reilly, C. A., \& Chandratat, I. (1990). Golden parachutes, CEOs, and the exercise of social influence. Administrative Science Quarterly, 35, 587-603.

Wade, J. B., Porac, J. F., Pollock, T. G., \& Graffin, S. D. (2006). The burden of celebrity: The impact of CEO certification contests on CEO pay and performance. Academy of Management Journal, 49, 643-660.

Weber, M. (1964). The theory of social and economic organization. Glencoe, IL: Free Press.

Westphal, J. D., \& Zajac, E. J. (1995). Who shall govern? CEO/Board power, demographic Similarity, and new director selection. Administrative Science Quarterly, 40, 60-83.

Winfrey, F. L., \& Logan, J. E. (1998). Are Reputation and power compensating differentials in CEO compensation. Corporate Reputation Review, 2(1), 61-76. 
Wright, P., \& Kroll, M. (2002). Executive discretion and corporate performance as determinants of CEO compensation, contingent on external monitoring activities. Journal of Management and Governance, 6(3), 189-214.

Yermack, D. (1996). Higher market valuation of companies with a small board of directors. Journal of Financial Economics, 40, 185-211.

Stefan Winter is a professor of Human Resource Management at Ruhr-University Buchum. He received his doctoral degree in 1995 at Humboldt-University and held chair for Business Administration and Organzation from 1998 to 2004 in Würzburg. His research interests are in executive compensation, gambling markets, education systems, and personnel economics.

Philip Michels is Research Associate at the chair of Human Resource Management at Ruhr-University Bochum, Germany. He is Graduate in Management and Economics and received his PhD at Ruhr-University Bochum in 2018. His research interests include management compensation, corporate governance, and research on (bargaining) power. 